\title{
DISCLAIMER
}

This report was prepared as an account of work sponsored by an agency of the United States Government. Neither the United States Government nor any agency thereof, nor any of their employees, makes any warranty, express or implied, or assumes any legal liability or responsibility for the accuracy, completeness, or usefulness of any information, apparatus, product, or process disclosed, or represents that its use would not infringe privately owned rights. Reference herein to any specific commercial product, process, or service by trade name, trademark, manufacturer, or otherwise does not necessarily constitute or imply its endorsement, recommendation, or favoring by the United States Government or any agency thereof. The views and opinions of authors expressed herein do not necessarily state or reflect those of the United States Government or any agency thereof.

$\mathrm{DOE} / \mathrm{N} / 10872--\mathrm{T} 7$

DE92 014665

\section{Semi- Annual Report}

\section{Supplemøntal Task A-2,A-2A}

\section{Design of Robust Waste Cannister}

\author{
Dr. Robert Skaggs \\ Waste Package Investigator
}

The original design for High Level Nuclear Waste cannisters anticipated

a dry and oxidizing environment and stable geological conditions.

For these conditions, a welded light walled cannister of type $316 \mathrm{~L}$

austenitic stainless steel was adequate. More recently, the possibility

of geological activity, has been raised, and with it the occurence

of mechanical loading, water immersion, and reducing conditions. 
In order to meet these new design conditions, a multi barrier containment system is proposed.

- An inner shell of Copper base alloy, to resist a wet, reducing environment

- An outer shell of a Nickel base Chromium alloy to resist the dry oxidizing conditions.

- A nonconducting oxide barrier to separate the two metallic barriers.

The imposition of an electrical and thermal insulation barrier raises questions concerning the adequacy of heat dissipation. Accordingly, the examination of the temperature distribution within the containment véssel as a function of Heat flux, Insulation type, Thickness, and Boundary conditions, become an integral part of the design. Of primary concern is the $350^{\circ} \mathrm{C}$ maximum temperature limit, which has been placed on the Zirconium alloy fuel rod sheaths.

The work of Pourbaix is of intrest, when we attempt to estimate the performance of metals in an aqueous environment. Pourbaix plots the chemical behavior of metals in water on a Potential-vs- $p H$ map. 
In general, three areas are observed.

- Immunity: In here, the metal is thermodynamically stable.

- Passivity: In here, corrosion occurs, but produces an insoluble product.

- Corrosion: In here, corrosion produces a soluble product.

A simplified Pourbaix Diagram of Iron is presented in fig. 1. As shown, Immunity occurs at lower potentials, while corrosion occurs at low $\mathrm{pH}$ and high potential and Passivity occurs at high $\mathrm{pH}$. The practical implications are obvious.

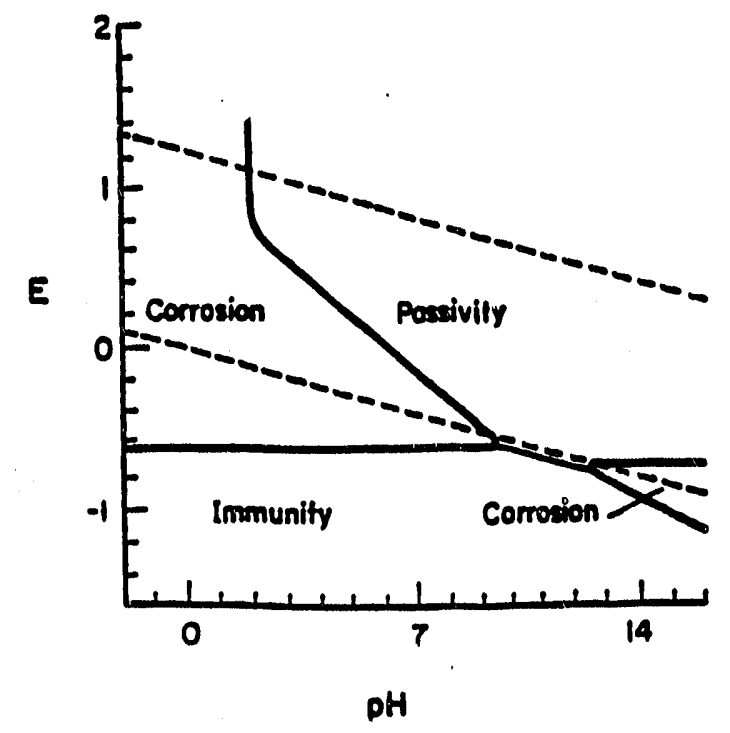

A simplified form of the Pourbaix diagram for iron" 
- Structures maintained, at a sufficiently low potential, by a D.C source or by a Sacrificial anode are immune to corrosion.

- In the case of Reinforced Concrete Structures, the alkaline conditions created by the cement, contributes to the resistence of the system. In recent years, the use of Cathodic protection in Reinforced Concrete structures is increasing in popularity.

- From the evidence discussed above, one might expect that an extremely long lived barrier might be formed, using corrosion resistant alloys, in an alkaline environment, protected by Sacrificial anodes.

In order to allow easy retrival of Nuclear Waste, no welded closure, would be performed, until the final decision for burial has been made. In order to achieve this end, lifting lugs, attached to the vertical cylinder, would be used rather tahn the single lifting pintol, which is an integral part of the welded head. The lifting lugs or lifting collar, could be made of an active metal and would serve a second function as a sacrificial anode. 
If the decision for the final disposal is made, a welded head would be placed on the Copper alloy inner container, either by Friction or Fusion welding process, also a fabricated concrete spacer disc, would be placed on top of the inner container, and the entire cavity filled with concrete. A longer, larger cylinder of high nickel alloy would then be lowered over the inner shell, to give the final Robust package shown below.

\section{CANNISTER EMPLACEMENT CONFIGURATION}

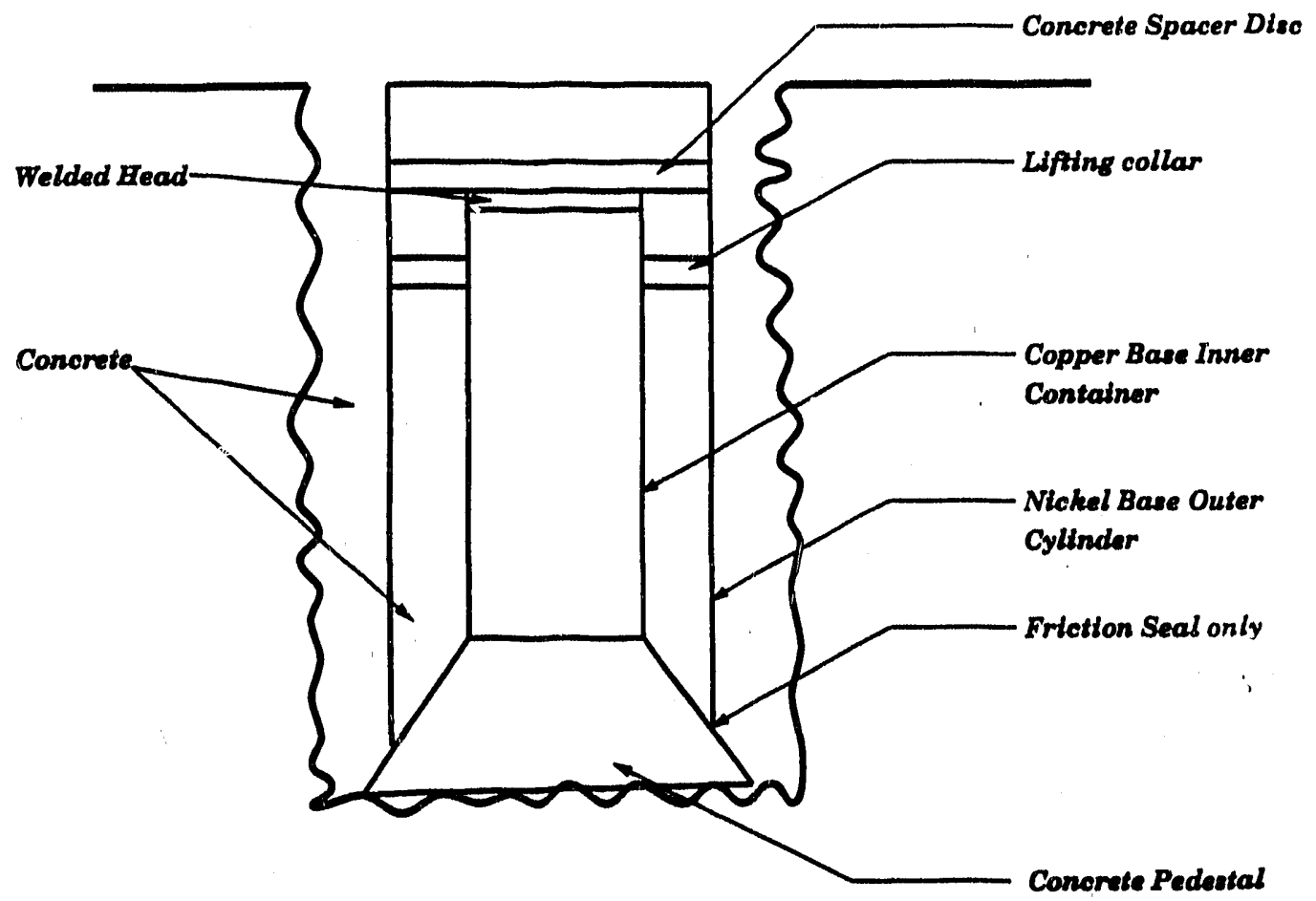




\section{References}

- CORROSION PRODUCT IDENTIFICATION AND RELATIVE RATES OF CORROSION OF CANDIDATE METALS IN AN IRRADIATED AIR-STEAM ENVIRONMENT, D.T.Reed, V.Swayambhunathan,

R.A.V.Konynenberg, Report UCRL-1 02597, Nov. 1989

- EVALUATION OF THE POST EMPLACEMENT ENVIRONMENT OF HIGH LEVEL RADIOACTIVE WASTE PACKAGES AT YUCCA MOUNTAIN, NEVADA, W.Glassley, Report UCRL-100609, March 1990

- STATUS OF INTEGRATED PERFORMANCE ASSESMENT OF THE WASTE PACKAGES AND ENGINEERED BARRIER SYSTEM, W.J.O'Connell, Report UCRL-102114, Jan. 1990

- PRELIMINARY TECHNIQUE ASSESMENT FOR NONDESTRUCTIVE EVALUATION CERTIFICATION OF THE NNWSI DISPOSAL CONTAINER CLOSURE, Robert.A.Day, Report UCID-21923

- FABRICATION AND CLOSURE DEVELOPMENT OF NUCLEAR WASTE CONTAINERS FOR STORGE AT NEVADA YUCCA MOUNTAIN, E.N.Russell, T.A.Nelson, H.A.Domain, D.F.Lacount, E.S.Robitz, K.O.Stein, Report UCRL-99519, April 1989

- INITIAL REPORT ON STRESS CORROSION CRACKING EXPERIMENTS USING ZIRCALLOY-4 SPENT FUEL CLADDING C-RINGS, H.D.Smith, Report WHC-EP. 0096, Sep. 1988

- REVIEW OF MODELS RELEVENT TO THE PREDICTION OF PERFORMANCE OF HIGH LEVEL RADIOACTIVE WASTE DISPOSAL CONTAINERS, J.C.Farmer, R.D.McCright, Report UCRL-100172, Nov. 1989 
- CURRENT STATUS OF WASTE PACKAGE DESIGNS FOR THE YUCCA MOUNT.IN PROJECT, L.B.Balloua, Report UCRL-100790, July 1989

- REFERENCE WASTE PACKAGE ENVIRONMENT REPORT, W.E.Glassey, Report UCRL-59726, Oct. 1986

- HIGH LEVEL NUCLEAR WASTE DISPOSAL, H.C.Burkholder,Proceedings of the International Topical Meeting on High Level Nuclear Waste Disposal Technology and Engineering, Pasco, Washington 


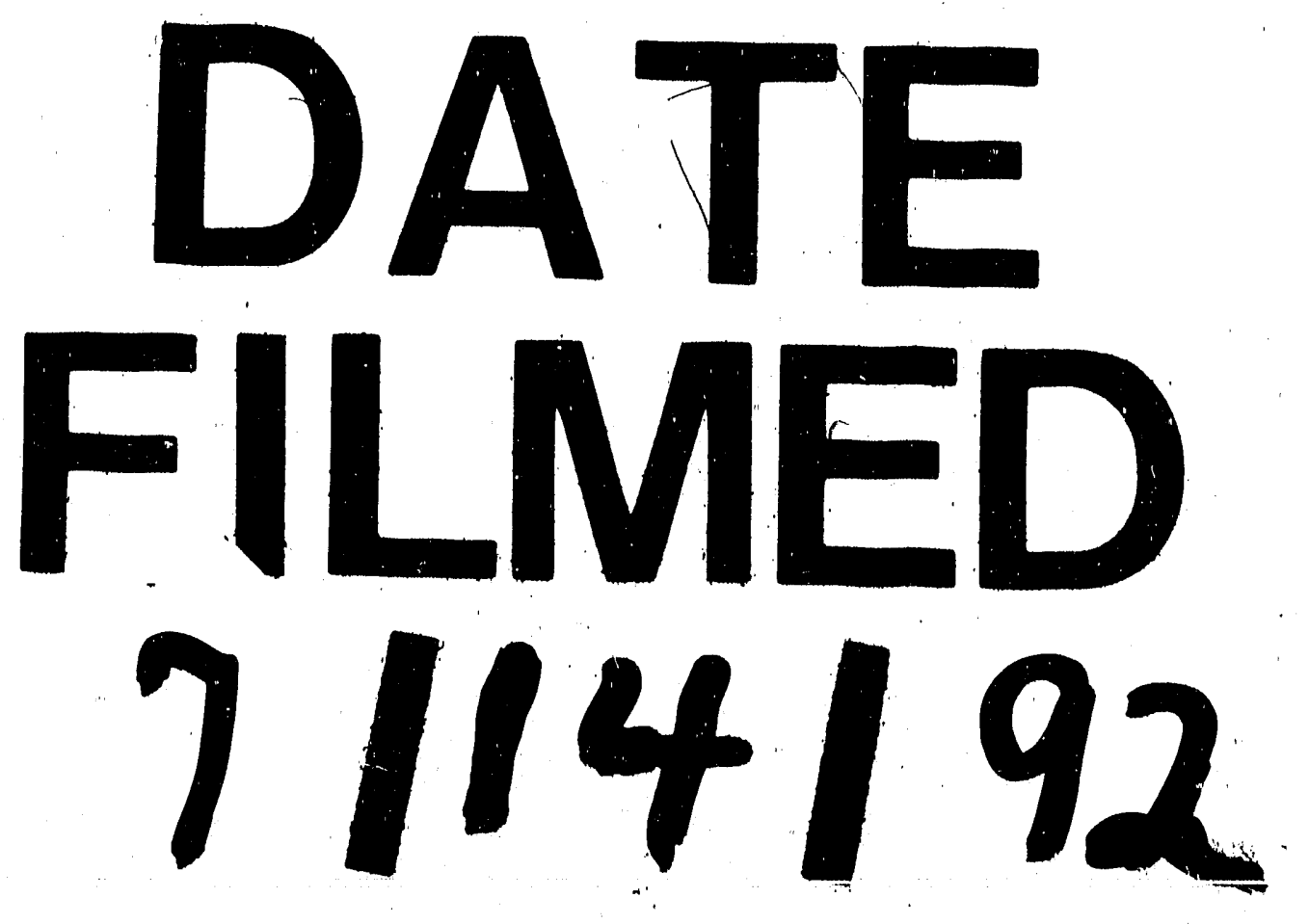




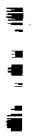

